\title{
Modelling flow and accreted ice in subglacial Lake Concordia, Antarctica
}

\author{
Malte Thoma ${ }^{\mathrm{a}, \mathrm{b}}$ Klaus Grosfeld ${ }^{\mathrm{a}}$ Irina Filina ${ }^{\mathrm{c}}$ \\ Christoph Mayer ${ }^{\mathrm{b}}$ \\ ${ }^{a}$ Alfred Wegener Institute for Polar and Marine Research, \\ Bussestrasse 24, 27570 Bremerhaven, Germany \\ ${ }^{\mathrm{b}}$ Bayerische Akademie der Wissenschaften, Kommission für Glaziologie, \\ Alfons-Goppel-Str. 11, 80539 München, Germany \\ ${ }^{\mathrm{c}}$ Jackson School of Geosciences, University of Texas, Austin, USA \\ Now at: Hess Corporation, 500 Dallas St., Houston, TX, 77002, USA
}

\begin{abstract}
More than 150 subglacial lakes have been discovered in Antarctica so far. Due to obvious challenges with exploration, numerical modelling remains one of the major tools to acquire information about those hard-to-access objects. Until now only the huge Lake Vostok has been investigated in detail. This paper focuses on Lake Concordia - the second largest subglacial lake in Antarctica over which substantial geophysical data has been collected. This lake is covered by about $4000 \mathrm{~m}$ ice and is located near Dome C. In order to apply numerical models to the hard-to-access Antarctic subglacial lakes, decent geometries and boundary conditions are required. In this study we present the results of airborne gravity inversion, suggesting that this lake has an area of $617 \mathrm{~km}^{2}$, a volume of $31 \mathrm{~km}^{3}$, and a maximum water column thickness of $126 \mathrm{~m}$. This bathymetry is used as geometry input for an established 3D-numerical lake-flow model to simulate the circulation and basal mass balance. Compared to our model studies of subglacial Lake Vostok, we obtain a general circulation pattern that is significantly weaker (due to the smaller size of the lake) and of reversed orientation (due to the reversed ice surface tilt). The modelled mean horizontal and vertical velocities are in the order of $0.2 \mathrm{~mm} / \mathrm{s}$ and $0.5 \mu \mathrm{m} / \mathrm{s}$, respectively. The larger molecular convective velocity estimations $(1.35 \pm 0.13 \mathrm{~mm} / \mathrm{s}$ and $0.81 \pm 0.08 \mathrm{~mm} / \mathrm{s}$ ) are similar to Lake Vostok's. The modelled average melting and freezing rates are $4.3 \pm 1.1 \mathrm{~mm} / \mathrm{a}$ and $1.1 \pm 0.3 \mathrm{~mm} / \mathrm{a}$, respectively, and the corresponding fresh water gain is $58 \pm 27 \mathrm{dm}^{3} / \mathrm{s}$. Integration of the modelled freezing and melting along prescribed ice flow lines allows us to calculate the distribution and thickness of accreted ice at the ice sheet bottom. We estimate a volume of $2.6 \pm 2.0 \mathrm{~km}^{3}$ ( $8.3 \pm 8.2 \%$ of the total lake volume) occupying the north-eastern corner of the lake covering an area of $159 \pm 48 \mathrm{~km}^{2}$ ( $26 \pm 9 \%$ of the total lake area). With about $16800 \pm 7600$ years, the residence time of the lake's water is significantly shorter than Lake Vostok's.
\end{abstract}

Key words: subglacial lakes, Lake Concordia, numerical modelling, Antarctica

Email address: Malte. Thoma@awi.de (Malte Thoma). 


\section{Introduction}

About 150 subglacial lakes have been identified in Antarctica so far (Siegert et al., 2005). The largest one - Lake Vostok - attracts much of scientific attention due to to the potential for extremophiles confined in the waters of the lake. The presence of a sustained microbial ecosystem in the subglacial environment is hypothesized, based on the analysis of accreted ice recovered from Lake Vostok's ice core. In this core higher concentrations of microbial remnants compared to the meteoric ice have been identified, indicating the potential existence of life forms in the lake, as was speculated over a long period of time (Souchez et al., 2003; Christner et al., 2006). Due to obvious difficulties with exploration of subglacial lakes, numerical modelling remains an important tool to examine internal processes, such as the water circulation or melting and freezing processes at the ice-water interface. Due to its large size, the majority of previous studies on Antarctic lakes have focused on Lake Vostok: Several geometric models have been constructed (Studinger et al., 2004; Roy et al., 2005; Filina et al., 2008), detailed information about the ice flow across the lake has been published (Kwok et al., 2000; Tikku et al., 2004), and some (more or less simplified) numerical flow models have been applied (Wüest and Carmack, 2000; Williams, 2001; Walsh, 2002; Mayer et al., 2003). Even a laboratory analogue study has been performed (Wells and Wettlaufer, 2008) indicating principle flow patterns. However, comparisons with these early models showed, that only with sophisticated 3D-models and a realistic bathymetry sensible results can be expected (Thoma et al., 2007a). Successive studies, applying the most reasonable boundary conditions, have investigated the circulation, the mass balance at the ice-lake interface, the tracer dispersion within the lake, and the amount of accreted ice at the icelake interface for Lake Vostok (Thoma et al., 2007a,b, 2008a,b; Filina et al., 2008), but no adequate information (e.g., water depth, ice thickness, grounding line, heat fluxes) was available about any other subglacial lake until now. In this study we turn towards Lake Concordia which is located near Dome C at $74.0^{\circ} \mathrm{S}$ and $125.2^{\circ} \mathrm{E}$ (see inlet in Figure $1 \mathrm{a}$ ) and many times smaller than Lake Vostok. We introduce the new bathymetry into our numerical flow model and investigate the mean flow pattern and the basal mass balance. The calculated melt and freeze rate is combined with the observed ice flow to derive the thickness and distribution of accreted ice at the ice-lake interface.

In Section 2 we describe the bathymetry model of Lake Concordia and the boundary conditions we used as input for our established numerical lake-flow model. The model results are briefly described in Section 3 before we discuss them with respect to information available for the much larger Lake Vostok in Section 4. The final Section 5 discusses flow patterns and basal mass balance conditions which are characteristic for a large range of subglacial lakes. 


\begin{tabular}{lrrrc}
\hline & & Lake & \multicolumn{2}{c}{ Lake Concordia } \\
& & Vostok & This study & Tikku \\
\hline Area & $\left(\mathrm{km}^{2}\right)$ & 16820 & 617 & 800 \\
Volume & $\left(\mathrm{km}^{3}\right)$ & 5061 & 31 & $200 \pm 40$ \\
Ice thickness average & $(\mathrm{m})$ & 4062 & 4055 & 4050 \\
\multicolumn{1}{c}{ min. } & $(\mathrm{m})$ & 3403 & 3948 & 3850 \\
& $(\mathrm{~m})$ & 4271 & 4116 & 4125 \\
Av. water column & $(\mathrm{m})$ & 318 & 59 & \\
Max. water column & $(\mathrm{m})$ & 1067 & 126 & $200-300$ \\
Zonal resolution & $\left({ }^{\circ}\right)$ & 0.10 & 0.0250 & \\
Merid. resolution & $\left(^{\circ}\right)$ & 0.05 & 0.0125 & \\
Nodes & & 1235 & 582 & \\
\hline
\end{tabular}

Table 1

Comparison of geometric parameters and flow models resolution for Lake Concordia and Lake Vostok (according to the geometry model derived by Filina et al. (2008) and applied in Thoma et al. (2008a)). The last column shows values for Lake Concordia published by Tikku et al. (2005).

\section{Geometry and numerical model setup}

Lake Concordia has been known since 1999-2000 when the University of Texas Institute for Geophysics (UTIG) performed an airborne geophysical survey in the Dome C area (Tikku et al., 2002; Blankenship, 2003; Filina et al., 2004, 2006). Spacing between the survey lines was $10 \mathrm{~km}$. The region of Lake Concordia is sampled with six gravity profiles, shown in Figure 1. The accuracy of free-air gravity data was estimated by comparing the measurements along repeated profiles, indicating a $1.6 \mathrm{mGal}\left(1 \mathrm{Gal}=0.01 \mathrm{~m} / \mathrm{s}^{2}\right) \mathrm{RMS}$ (root mean square) difference. The 3D-bathymetry model for Lake Concordia was developed via inversion airborne gravity data. If a density of $2670 \mathrm{~kg} / \mathrm{m}^{3}$ of the hosted rocks is assumed (as in Tikku et al., 2005), Lake Concordia has a size of $617 \mathrm{~km}^{2}$, a volume of $31 \mathrm{~km}^{3}$, and a mean water depth of $59 \mathrm{~m}$. The uncertainty in gravity data corresponds to the error in the inverted water thickness of $23 \mathrm{~m}$. The inversion suggests that Lake Concordia's basin has a gently deepening western border and a relatively steep eastern one, with the maximum water depth in the north-eastern part of the lake. Figure 1 shows the ice and water column thickness, while Table 1 compares parameters of the used geometry with those presented by Tikku et al. (2005), as well as spatial information about Lake Vostok for comparison (as applied in Thoma et al., 2008a). The large volume difference to Tikku et al. (2005) arises from 


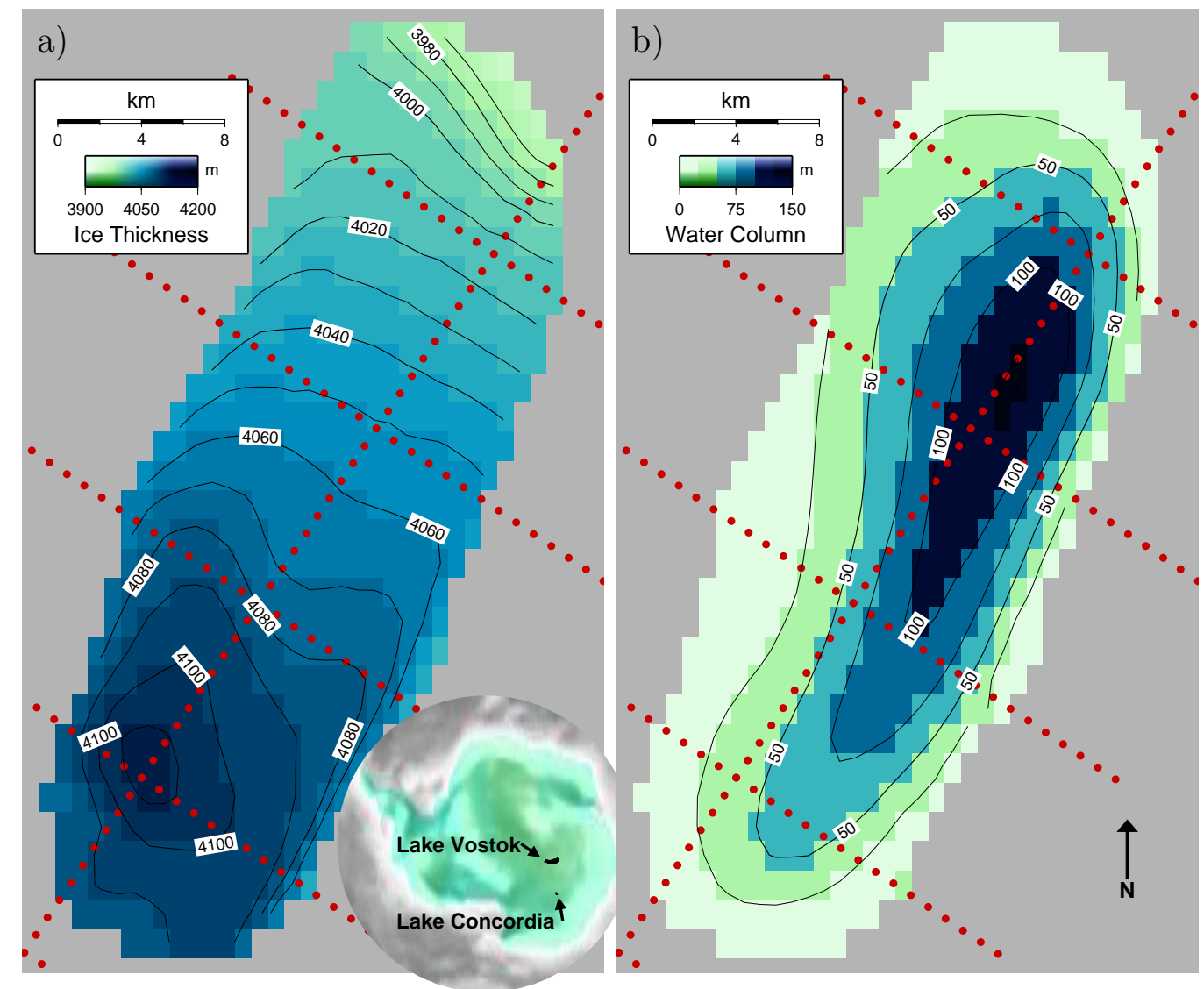

Fig. 1. Ice Thickness (a) and water column thickness (b) of Lake Concordia. Red dots indicate gravity profiles. The embedded figure in a) shows the location in Antarctica of Lake Vostok and Lake Concordia.

their simplified horizontal dimensions $(40 \mathrm{~km} \times 20 \mathrm{~km})$ and an overestimated (constant) water depth of $250 \mathrm{~m}$.

Details about the numerical ocean/lake flow model Rombax are described in Grosfeld et al. (1997) and Thoma et al. (2006, 2007a, 2008b); here we concentrate on the differences between the set up used to model Lake Vostok and the set up applied in this study. Lake Concordia's area (volume) is only $3.6 \%$ $(0.6 \%)$ of Lake Vostok's; hence we increased the horizontal resolution of our flow model Rombax by four (resulting in a grid size of about $0.8 \mathrm{~km} \times 1.4 \mathrm{~km}$ ) to obtain a reasonable number of nodes. Along with this, an adjustment of the horizontal $\left(A_{h}\right)$ and vertical $\left(A_{v}\right)$ eddy viscosities is necessary. These values represent the macroscopic diffusion of momentum, which cannot be resolved by this type of circulation models, and are closely related to the grid size. As in Thoma et al. (2007a), several parametrizations of the horizontal $\left(A_{h}\right)$ and vertical $\left(A_{v}\right)$ eddy viscosities have been tested. Finally we applied viscosities which are four times lower than those used to model Lake Vostok $\left(A_{h}=5 \mathrm{~m}^{2} / \mathrm{s}\right.$, $\left.A_{v}=0.025 \mathrm{~cm}^{2} / \mathrm{s}\right)$. These values are a good compromise between suppressing important circulation features (by to much diffusion) and numerical noise (by to low diffusion). The horizontal diffusion is also consistent with the rough 
estimation formular $A_{h}=(L \cdot v) / 2$, with the length scale $L=10 \mathrm{~km}$ and a typical horizontal velocity of about $v=1 \mathrm{~mm} / \mathrm{s}$. A Prandtl number of unity is choosen, which results in identical values for the diffusion of heat. According to Thoma et al. (2007a), this is suitable for the modelling of subglacial lakes. In the vertical, sixteen terrain-following layers with a minimum thickness of $0.5 \mathrm{~m}$ are used. According to Tikku et al. (2005), the geothermal heat flux into Lake Concordia is $Q_{\mathrm{Geo}}=57 \mathrm{~mW} / \mathrm{m}^{2}$. A value which is also consistent with the work of Maule et al. (2005), who interpreted satellite magnetic data with respect to the geothermal heat flux underneath the Antarctic Ice Sheet. However, to test the sensitivity of our model towards this parameter, we also apply values of $Q_{\mathrm{Geo}}=47 \mathrm{~mW} / \mathrm{m}^{2}$ and $Q_{\mathrm{Geo}}=67 \mathrm{~mW} / \mathrm{m}^{2}$. The heat flux $Q_{I}$ into the ice can be calculated from the average ice thickness $H=4055 \mathrm{~m}$, the heat conductivity of ice $\lambda=2.1 \mathrm{~W} /(\mathrm{Km})$ and the difference between the pressure-dependent freezing point at the lake's surface $T_{p}=-2.7^{\circ} \mathrm{C}$ and the ice's surface temperature $T_{s}: Q_{\mathrm{I}}=\lambda\left(T_{s}-T_{p}\right) / H$. Taking temperature variations $\left(\Delta T \approx 12^{\circ} \mathrm{C}\right)$ over the last glacial cycles into account and considering the present-day temperature $\left(T_{s} \approx-54^{\circ} \mathrm{C}\right)$ at Dome $\mathrm{C}$ as a reference (i.e. Tikku et al., 2005), the heat flux into the ice is calculated to be $24.5-30.7 \mathrm{~mW} / \mathrm{m}^{2}$. The average value is about $Q_{I}=28.6 \mathrm{~mW} / \mathrm{m}^{2}$ as the mean surface temperature is approximately $T_{s}=-58^{\circ} \mathrm{C}$. With this estimation, the lake's heat loss through the ice sheet is about half the geothermal heat gain. Alternatively, a temperature gradient of $2.22^{\circ} \mathrm{C} / 100 \mathrm{~m}$, determined from borehole measurements at the close by EPICA drill site, is used (C. Ritz pers. comm, 2008). This leads to a heat flux into the ice of $Q_{I}=46.6 \mathrm{~mW} / \mathrm{m}^{2}$.

\section{Results}

In the following we briefly present the model results of Lake Concordia with respect to the flow regime (Section 3.1) and the basal mass balance (Section 3.2). A compilation of important model results is given in Table 2. Note, that all model results are rather predictions than facts, since until measurements within subglacial Lake Concordia have been performed a model validation is limited.

\subsection{Circulation}

The vertically integrated mass transport stream function (Figure 2a) is divided into two parts, an anticyclonic (anticlockwise) gyre of about $-0.10 \mathrm{mSv}$ $\left(1 \mathrm{mSv}=1000 \mathrm{~m}^{3} / \mathrm{s}\right)$ in the northern part and a stronger $(0.26 \mathrm{mSv})$ cyclonic gyre in the southern part of Lake Concordia. The zonal and meridional overturning exceeds strengths of about $100 \mu \mathrm{Sv}$ and $25 \mu \mathrm{Sv}$, respectively (Figure 3). 


\begin{tabular}{|c|c|c|c|c|c|c|c|}
\hline & & \multirow{3}{*}{$\begin{array}{c}\text { Lake } \\
\text { Vostok }\end{array}$} & \multicolumn{5}{|c|}{ Lake Concordia } \\
\hline & & & \multicolumn{4}{|c|}{ This study } & \multirow[t]{2}{*}{ Tikku et al. (2004) } \\
\hline & & & \multicolumn{3}{|c|}{ Modeled values ${ }^{\dagger}$} & Average value ${ }^{\ddagger}$ & \\
\hline Min. stream func. & $(\mathrm{mSv})$ & -25 & $\begin{array}{l}-0.09 \\
-0.09\end{array}$ & $\begin{array}{l}-0.10 \\
-0.10\end{array}$ & $\begin{array}{l}-0.10 \\
-0.10\end{array}$ & $-0.10 \pm 7 \%$ & \\
\hline Max. stream func. & $(\mathrm{mSv})$ & +25 & $\begin{array}{l}0.24 \\
0.24\end{array}$ & $\begin{array}{l}0.26 \\
0.26\end{array}$ & $\begin{array}{l}0.27 \\
0.27\end{array}$ & $0.26 \pm 6 \%$ & \\
\hline Merid. overturning & $(\mathrm{mSv})$ & +5 & $\begin{array}{l}-0.024 \\
-0.024\end{array}$ & $\begin{array}{l}-0.026 \\
-0.026\end{array}$ & $\begin{array}{l}-0.028 \\
-0.028\end{array}$ & $-0.026 \pm 8 \%$ & \\
\hline Zonal overturning & $(\mathrm{mSv})$ & -19 & $\begin{array}{l}0.096 \\
0.096\end{array}$ & $\begin{array}{l}0.102 \\
0.102\end{array}$ & $\begin{array}{l}0.109 \\
0.109\end{array}$ & $0.102 \pm 6 \%$ & \\
\hline Velocity (horizontal) & $(\mathrm{mm} / \mathrm{s})$ & 1 & & & $\approx 0.2$ & & \\
\hline (vertical) & $(\mu \mathrm{m} / \mathrm{s})$ & 10 & & & $\approx 0.5$ & & \\
\hline Turb. kin. energy & $\left(10^{-2} \mathrm{~cm}^{2} / \mathrm{s}^{2}\right)$ & 3.5 & $\begin{array}{l}0.113 \\
0.113\end{array}$ & $\begin{array}{l}0.127 \\
0.126\end{array}$ & $\begin{array}{l}0.141 \\
0.142\end{array}$ & $0.127 \pm 0.11 \%$ & \\
\hline Freezing area & $\left(\mathrm{km}^{2}\right)$ & 4389 & $\begin{array}{l}152 \\
190\end{array}$ & $\begin{array}{l}122 \\
157\end{array}$ & $\begin{array}{c}87 \\
131\end{array}$ & $140 \pm 38 \%$ & 370 to $480^{\S}$ \\
\hline Mean melt rate & $(\mathrm{mm} / \mathrm{a})$ & 22 & $\begin{array}{l}4.0 \\
3.2\end{array}$ & $\begin{array}{l}4.7 \\
3.8\end{array}$ & $\begin{array}{l}5.3 \\
4.5\end{array}$ & $4.3 \pm 25 \%$ & $6.0 \pm 0.9$ \\
\hline Mean freeze rate & $(\mathrm{mm} / \mathrm{a})$ & 28 & $\begin{array}{l}1.1 \\
1.2\end{array}$ & $\begin{array}{l}1.1 \\
1.4\end{array}$ & $\begin{array}{l}0.8 \\
1.1\end{array}$ & $1.1 \pm 28 \%$ & $6.0 \pm 0.9$ \\
\hline Fresh water gain & $\left(10^{-1} \mathrm{~m}^{3} / \mathrm{s}\right)$ & 16 & $\begin{array}{l}0.52 \\
0.34\end{array}$ & $\begin{array}{l}0.67 \\
0.47\end{array}$ & $\begin{array}{l}0.85 \\
0.63\end{array}$ & $0.58 \pm 47 \%$ & \\
\hline Basal ice loss & $\left(10^{-2} \mathrm{~km}^{3} / \mathrm{a}\right)$ & 5.8 & $\begin{array}{l}0.16 \\
0.11\end{array}$ & $\begin{array}{l}0.21 \\
0.15\end{array}$ & $\begin{array}{l}0.27 \\
0.20\end{array}$ & $0.18 \pm 47 \%$ & \\
\hline Accreted ice area & $\left(\mathrm{km}^{2}\right)$ & $10800 \pm 500$ & $\begin{array}{l}163 \\
207\end{array}$ & $\begin{array}{l}141 \\
178\end{array}$ & $\begin{array}{l}111 \\
154\end{array}$ & $159 \pm 30 \%$ & \\
\hline volume & $\left(\mathrm{km}^{3}\right)$ & 500 & $\begin{array}{l}2.1 \\
4.3\end{array}$ & $\begin{array}{l}1.9 \\
4.1\end{array}$ & $\begin{array}{l}0.6 \\
2.3\end{array}$ & $2.6 \pm 76 \%$ & $55 \pm 5$ \\
\hline average & hickness (m) & $50 \pm 10$ & $\begin{array}{l}13.1 \\
20.6\end{array}$ & $\begin{array}{l}13.5 \\
22.9\end{array}$ & $\begin{array}{c}5.3 \\
15.2\end{array}$ & $15.1 \pm 65 \%$ & 125 \\
\hline Melting rate in meted & ic $\operatorname{area}(\mathrm{mm} / \mathrm{a})$ & $26.5 \pm 10$ & $\begin{array}{l}3.9 \\
3.1\end{array}$ & $\begin{array}{l}4.8 \\
3.8\end{array}$ & $\begin{array}{l}5.3 \\
4.5\end{array}$ & $4.2 \pm 27 \%$ & \\
\hline Lake water residence & (ka) & $32 \pm 4$ & $\begin{array}{l}17.5 \\
24.4\end{array}$ & $\begin{array}{l}13.6 \\
18.6\end{array}$ & $\begin{array}{l}11.6 \\
14.9\end{array}$ & $16.8 \pm 45 \%$ & \\
\hline
\end{tabular}

Table 2

Comparison of model results for Lake Vostok (according to the model presented in Thoma et al., 2008a) and for Lake Concordia from this study and from Tikku et al. (2004).

${ }^{\dagger}$ : The modelled results are arranged as follows: First row: $Q_{I}=28.6$, second row: $Q_{I}=46.6$, first column: $Q_{\mathrm{Geo}}=47 \mathrm{~mW} / \mathrm{m}^{2}$, second column: $Q_{\mathrm{Geo}}=57 \mathrm{~mW} / \mathrm{m}^{2}$, third column: $Q_{\text {Geo }}=67 \mathrm{~mW} / \mathrm{m}^{2}$.

$\ddagger$ : The average value referes to the mean of the six modelled results and the corresponding standard deviation (root-mean square).

$\S$ : These values correspond to $60 \%$ (as suggested by Tikku et al., 2004) of $617 \mathrm{~km}^{2}$ and $800 \mathrm{~km}^{2}$ (compare Table 1 ).

The sensitivity of the circulation to the applied thermal forcing by geothermal heat is less than $10 \%$. In our model simulation, the upwelling area in Lake Concordia is located in the west (Figure 2b). Bottom water is transported mainly north-westward with velocities of about $0.2 \mathrm{~mm} / \mathrm{s}$, as indicated by black arrows in Figure 2b. The maximum vertical velocity in Lake Concordia is in the order of $1 \mu \mathrm{m} / \mathrm{s}$. The flow in the upper lake levels (black arrows in Figure $4 \mathrm{a}+\mathrm{c}$ ) is of the same order as at the bottom, but mainly orientated in opposite direction to the south-east. An exception is the northern tip of the lake, where freezing 

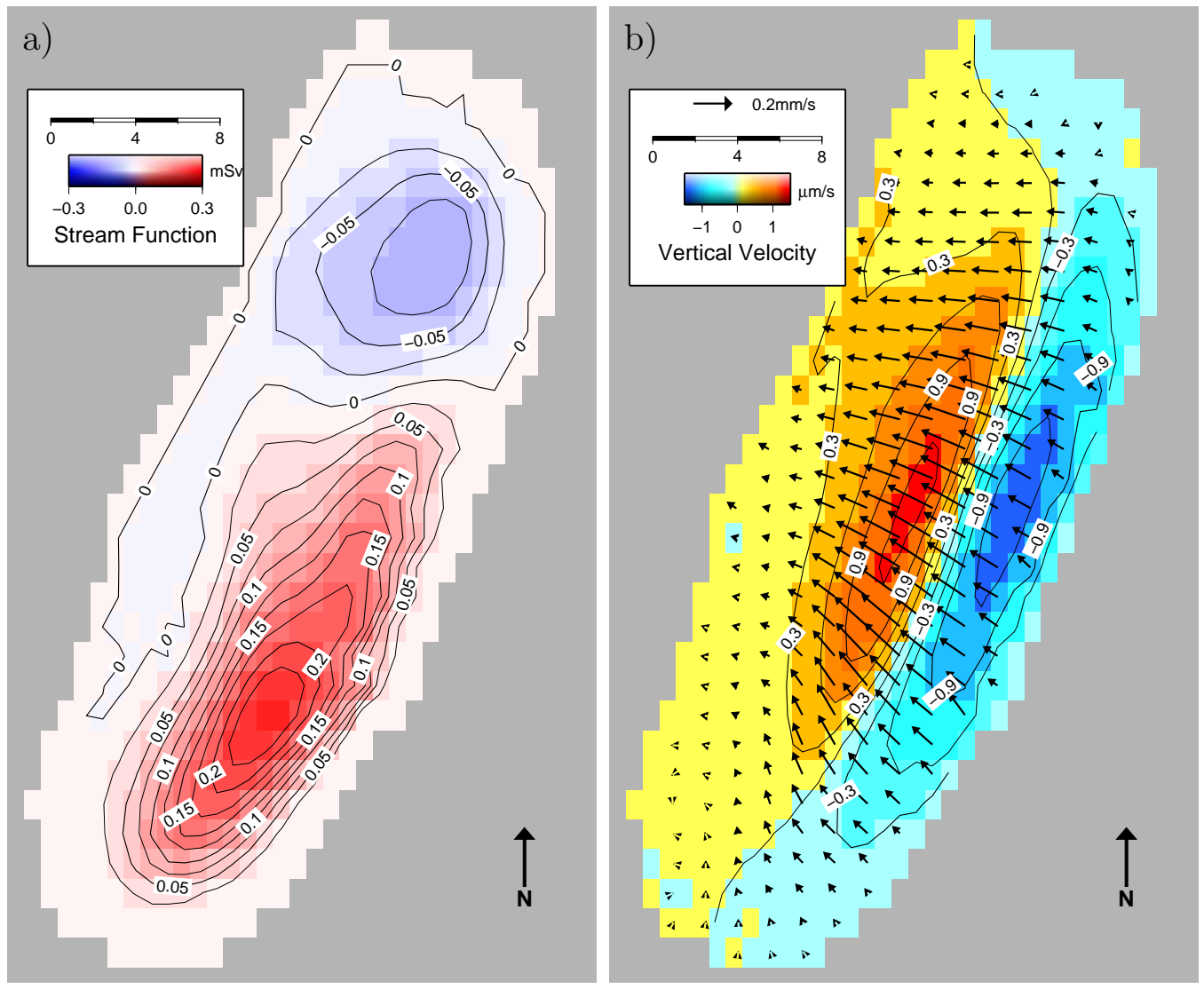

Fig. 2. Modelled (a) vertically integrated mass transport stream function $\left(1 \mathrm{mSv}=1000 \mathrm{~m}^{3} / \mathrm{s}\right)$ and (b) integrated vertical velocity with arrows indicating the bottom flow for a thermal forcing of $Q_{I}=28.6 \mathrm{~mW} / \mathrm{m}^{2}$ and $Q_{\mathrm{Geo}}=57 \mathrm{~mW} / \mathrm{m}^{2}$.

(see Section 3.2) causes a significant flow velocity increase to the north-west in the lake's upper part and hence induces the already mentioned anticyclonic gyre in this part of Lake Concordia.

\subsection{Basal mass balance and ice accretion}

While the circulation within Lake Concordia is quite insensitive to different thermal forcing, this is not the case for the modelled basal mass balance. Consequently, we present figures for two extreme thermal forcing scenarios: One where the geothermal heating is much larger than the heat loss through the ice $\left(Q_{\mathrm{Geo}}>Q_{I}\right)$ and the other where both parameters are quite similar $\left(Q_{\text {Geo }} \approx Q_{I}\right)$. The results are shown in Figure 4, while calculated values are presented in Tabular 2.

In freezing areas (yellowish color in Figure $4 \mathrm{a}+\mathrm{c}$ ) no heat conduction into the ice takes place and, consequently, no heat is extracted from the lake in these regions $\left(Q_{I}^{\text {freeze }}=0 \mathrm{~mW} / \mathrm{m}^{2}\right)$. This results in a net freshwater gain for 


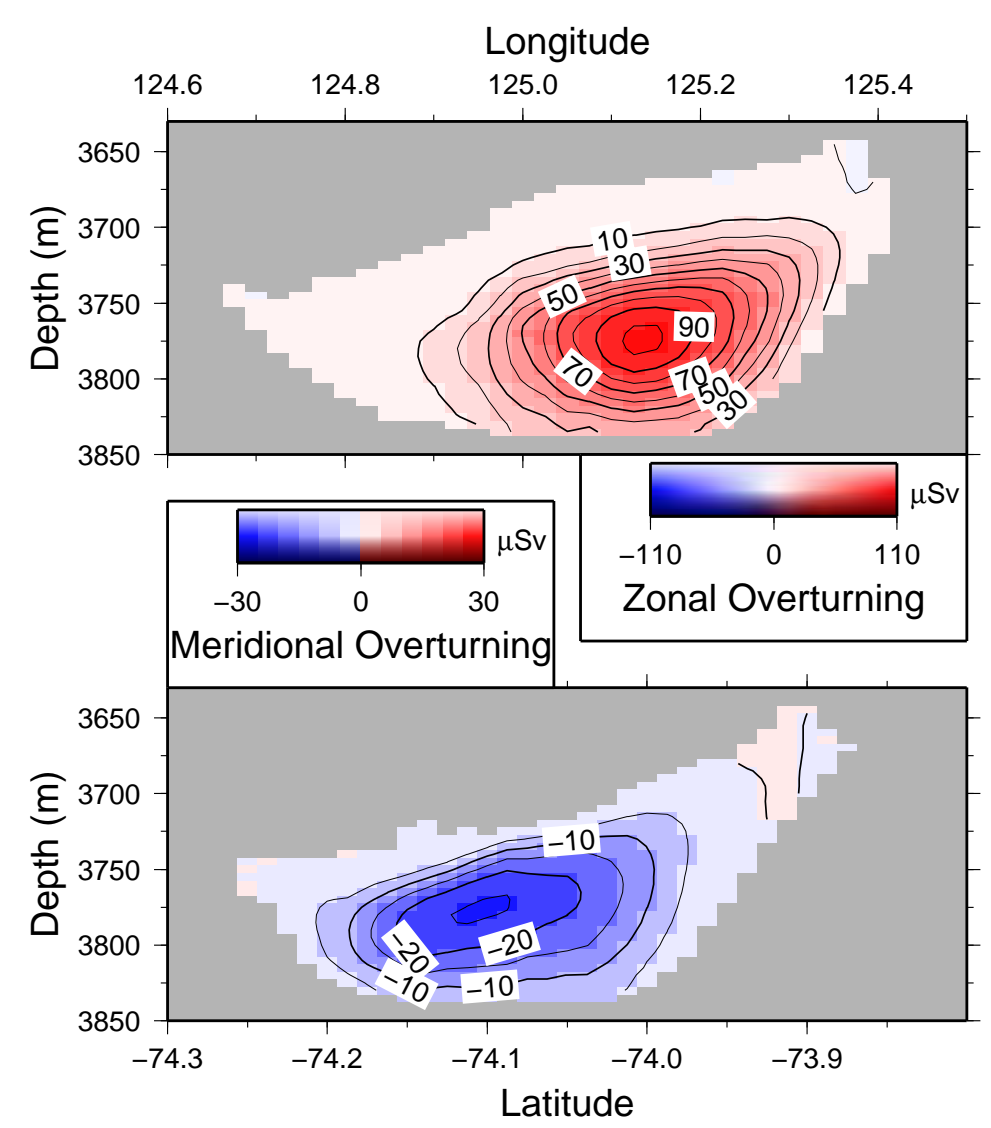

Fig. 3. Zonal and meridional overturning for a thermal forcing of $Q_{I}=28.6 \mathrm{~mW} / \mathrm{m}^{2}$ and $Q_{\mathrm{Geo}}=57 \mathrm{~mW} / \mathrm{m}^{2}$.

the lake (or ice loss), even when the heat flux through the ice exceeds the geothermal heat flux $\left(Q_{I}>Q_{\text {Geo }}\right)$. This feature has been discussed in detail in Thoma et al. (2008b). The mean melt rate is $4.3 \mathrm{~mm} / \mathrm{a} \pm 25 \%$ (depending on the heat fluxes). Freezing is restricted to the shallower area in the north (and a negligible tiny eastern edge) of $140 \mathrm{~km}^{2} \pm 38 \%$ with an average value of $1.1 \mathrm{~mm} / \mathrm{a} \pm 25 \%$. Melting is dominant, and the overall ice-mass loss is about $1.8 \cdot 10^{-3} \mathrm{~km}^{3} / \mathrm{a} \pm 47 \%$, equivalent to a fresh water flux of $5.8 \cdot 10^{-2} \mathrm{~m}^{3} / \mathrm{s} \pm 47 \%$.

The accreted ice distribution, shown in Figure $4 \mathrm{~b}+\mathrm{d}$, is modelled by applying an ice flow field heading east-northeastward with a velocity of $25 \mathrm{~cm} / \mathrm{a}$ as proposed by Tikku et al. (2005). This slow-moving flow field is combined with the modelled basal mass balance (Figure $4 a+c)$ to derive the accreted ice thickness by integration along ice flowlines (Thoma et al., 2008a).

We calculate an average area of $159 \mathrm{~km}^{2} \pm 30 \%$, a volume of $2.6 \mathrm{~km}^{3} \pm 76 \%$ and an average ice thickness of $15.1 \mathrm{~m} \pm 65 \%$ of accreted ice in the north-eastern corner of Lake Concordia. The average melting rate in the residual meteoric ice area is about $4.2 \mathrm{~mm} / \mathrm{a} \pm 27 \%$. 

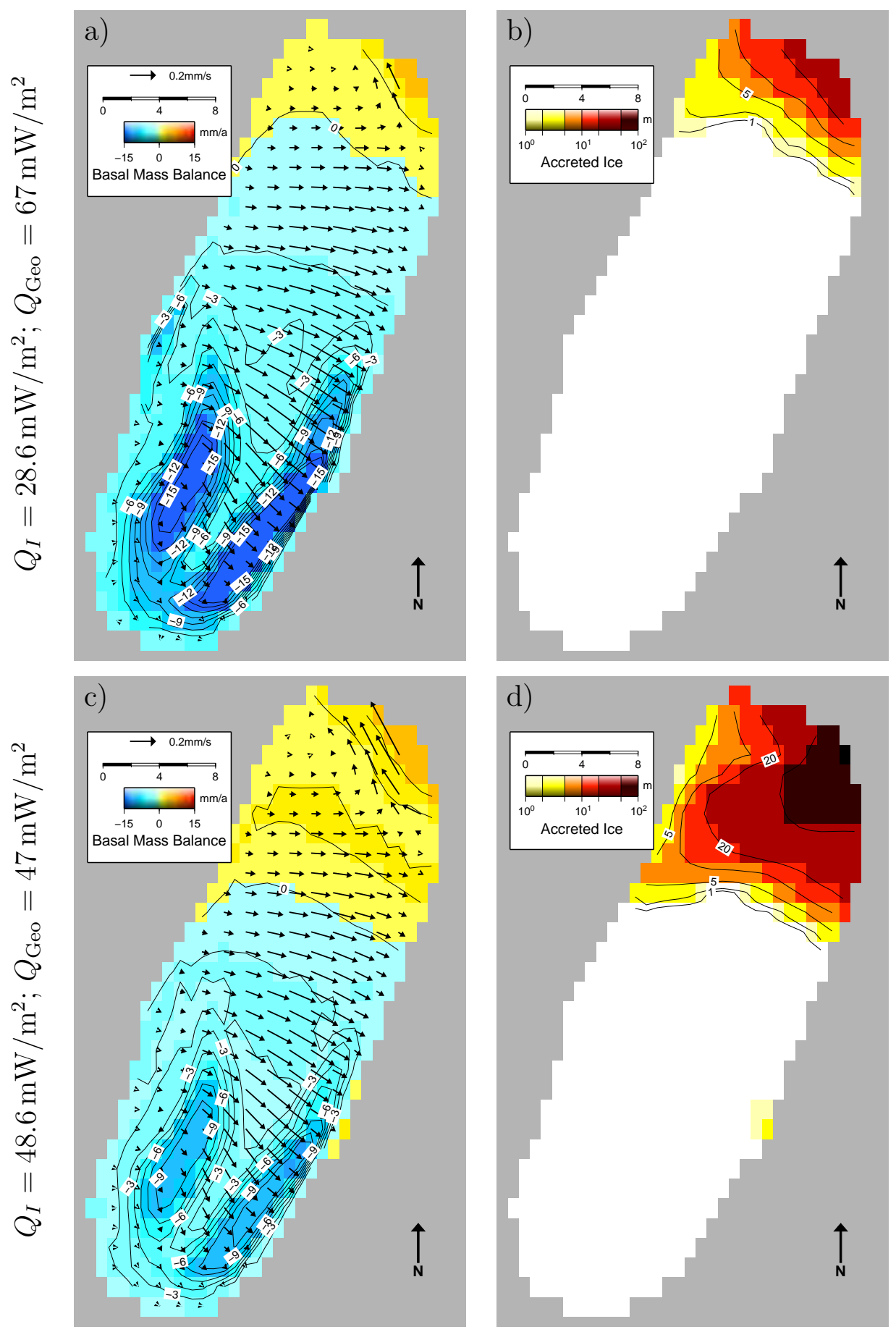

Fig. 4. Modelled basal mass balance at the ice-lake interface (a and c) as well as modelled accreted ice distribution and thickness (b and d) for the two applied extreme thermal forcing scenarios (indicated at the left). Negative values for the basal mass balance (int a and c) indicate melting, positive values freezing. 


\section{Discussion}

The modelled velocities, stream function, zonal and meridional overturning, and the turbulent kinetic energy in Lake Concordia are significantly smaller than their counterparts in Lake Vostok (Table 2). The main reason for this is the much smaller size of the lake. But it has to be noted that our model is limited and does not resolve eddies and/or convection, instead it uses eddy diffusivities and a convective adjustment scheme to derive averaged flow fields. This is sufficient to describe the general flow pattern and the basal mass balance at the ice-lake interface. In order to compare our model approach with possible in-situ properties, we use theoretical equations for the horizontal eddy scale $\left(\mathcal{R}=15 \sqrt{B / f^{3}}\right)$ and the larger convective velocities $\left(u_{h}=2.4 \sqrt{B / f}, u_{v}=4 \sqrt{B / f}\right)$ (e.g., Wüest and Carmack, 2000; Wells and Wettlaufer, 2008). The Coriolis parameter $f=1.4 \times 10^{-4} \mathrm{~s}^{-1}$ is nearly identical for both lakes. The buoyancy flux $B$ is equivalent to the geothermal heat flux $Q_{\mathrm{Geo}}$ and the pressure- and temperature-dependent thermal expansion $\alpha: B=g \alpha Q_{\mathrm{Geo}} /\left(\rho c_{p}\right)$, with $\rho c_{p}=4.2 \times 10^{6} \mathrm{~J} /\left(\mathrm{Km}^{3}\right), g=9.81 \mathrm{~m} / \mathrm{s}^{2}$, and $\alpha=-\rho^{-1} \partial \rho / \partial T$. In Table 3 representative values for depth and temperature are given as well as the described estimates for Lake Concordia and Lake Vostok, respectively. Our values of the thermal expansion coefficient exceed those given in Wüest and Carmack (2000) significantly by about an order of magnitude (compare Table 3). This results from a different parametrization for the equation of state (Chen and Millero, 1986; Millero and Poisson, 1981; Jackett and McDougall, 1995) and its sensitivity to temperature derivations. However, with respect to the large uncertainties involved in subglacial environment velocity estimations, the impact of the different thermal expansion coefficients on the buoyancy flux and the estimated velocities (which differ by about a factor of two to three from those estimated in Wüest and Carmack (2000) and Wells and Wettlaufer (2008)) is acceptable. Despite the large differences in the geometry the characteristic molecular velocities and eddy scales are very close for both lakes.

According to the basal mass exchange, the freezing area fractions of both lakes are similar ( $21 \%$ for Lake Vostok, $\approx 23 \%$ for Lake Concordia). These do depend on the available energy (which is the difference between the energy provided by the geothermal heat and the heat loss through the ice sheet), the ice thickness and the surface slope (Thoma et al., 2008b). In this respect Lake Concordia and Lake Vostok may be seen as typical representatives for subglacial lakes. The larger average melt and freeze rates modelled for Lake Vostok result from the stronger advection of water along the ice-lake interface. However, due to the much smaller volume of Lake Concordia, the relative basal ice loss is significantly larger: About $0.004 \%$ to $0.009 \%$ of the lake's volume is added per year, compared to only $0.001 \%$ per year for Lake Vostok. 


\begin{tabular}{|c|c|c|c|c|c|}
\hline & & & $\begin{array}{c}\text { Lake } \\
\text { Vostok } \\
\text { WC\&WW }\end{array}$ & $\begin{array}{c}\text { Lake } \\
\text { Vostok } \\
\text { Thoma et al. }\end{array}$ & $\begin{array}{c}\text { Lake } \\
\text { Concordia } \\
\text { This study }\end{array}$ \\
\hline Depth & $D$ & $(\mathrm{~m})$ & 3700 to 4200 & 4000 & 3750 \\
\hline Temperature & $T$ & $\left({ }^{\circ} \mathrm{C}\right)$ & -2.83 to -2.53 & -3.0 & -2.7 \\
\hline Density & $\rho$ & $\left(\mathrm{kg} / \mathrm{m}^{3}\right)$ & 1015 to 1017 & 1019.6 & 1018.4 \\
\hline Therm. exp. coef. & $\alpha$ & $\left(10^{-6 \circ} \mathrm{C}^{-1} 1\right)$ & 18 & 133 & 121 \\
\hline Geoth. heat flux & $Q_{\mathrm{Geo}}$ & $\left(\mathrm{mW} / \mathrm{m}^{2}\right)$ & 40 to 50 & 54 & 47 to 67 \\
\hline Buoyancy flux & $B$ & $\left(10^{-11} \mathrm{~W} / \mathrm{kg}\right)$ & 0.15 to 0.26 & 1.68 & 1.32 to 1.89 \\
\hline Vert. vel. & $u_{v}$ & $(\mathrm{~mm} / \mathrm{s})$ & 0.30 & 0.83 & 0.73 to 0.88 \\
\hline Horiz. vel. & $u_{h}$ & $(\mathrm{~mm} / \mathrm{s})$ & 0.34 & 1.39 & 1.22 to 1.47 \\
\hline Horiz. eddy scale & $\mathcal{R}$ & $(\mathrm{m})$ & 10 to 30 & 37 & 33 to 39 \\
\hline
\end{tabular}

Table 3

Physical parameters and estimations of horizontal and vertical convective velocities and eddy scales for Lake Concordia and Lake Vostok. Values for Lake Vostok refere to Thoma et al. (2007a, 2008b) as well as to Wüest and Carmack (2000) and Wells and Wettlaufer (2008), respectively. Values for Lake Concordia cover the sensitivity range for heat fluxes applied in this study.

These values would correspond to a surface uplift of 2.0 to $4.5 \mathrm{~mm} / \mathrm{a}$ for Lake Concordia and $3.0 \mathrm{~mm} / \mathrm{a}$ for Lake Vostok.

According to Tikku et al. (2004) freezing of ice at the lake-ice boundary exceeds melting by about 30-50\% in Lake Concordia, resulting in either an ongoing reduction in lake volume, an indication of significant transport of water into the lake from a subglacial hydrological system or an underestimated amount of melting. In contrast to this, our model with a geothermal heat flux about 1.0 to 2.3 times the amount of heat loss through the ice cover, which is zero in areas where freezing takes place, indicates a lake growth of about 3.4 to $8.5 \cdot 10^{-2} \mathrm{~m}^{3} / \mathrm{s}\left(\approx 1.1\right.$ to $\left.2.7 \cdot 10^{-3} \mathrm{~km}^{3} / \mathrm{a}\right)$. If the lake is not losing water through a subglacial hydrological system (as shown at other locations, e.g., Gray et al., 2005; Wingham et al., 2006; Fricker et al., 2007), long term high precision GPS measurements could detect if the lake is growing or shrinking.

Our modelled average accreted ice thickness $15.1 \pm 65 \%$ in the north-eastern edge of Lake Concordia is significantly lower than those of Tikku et al. (2005) $(125 \mathrm{~m})$, which surpasses the average water column thickness of Lake Concordia.

A lake water residence time of about 11600 to 24400 years can be estimated by dividing the lake's volume $\left(31 \mathrm{~km}^{3}\right)$ by the meteoric ice area $\left(410\right.$ to $\left.506 \mathrm{~km}^{2}\right)$ 
and the corresponding average melt rates 3.1 to $5.3 \mathrm{~mm} / \mathrm{a}$. These values are significantly shorter than the estimated residence time of the water within Lake Vostok (32 $\pm 4 \mathrm{ka}$, Thoma et al., 2008a) and indicate that the lake water could have been replaced twice since the last glacial maximum.

\section{Conclusion}

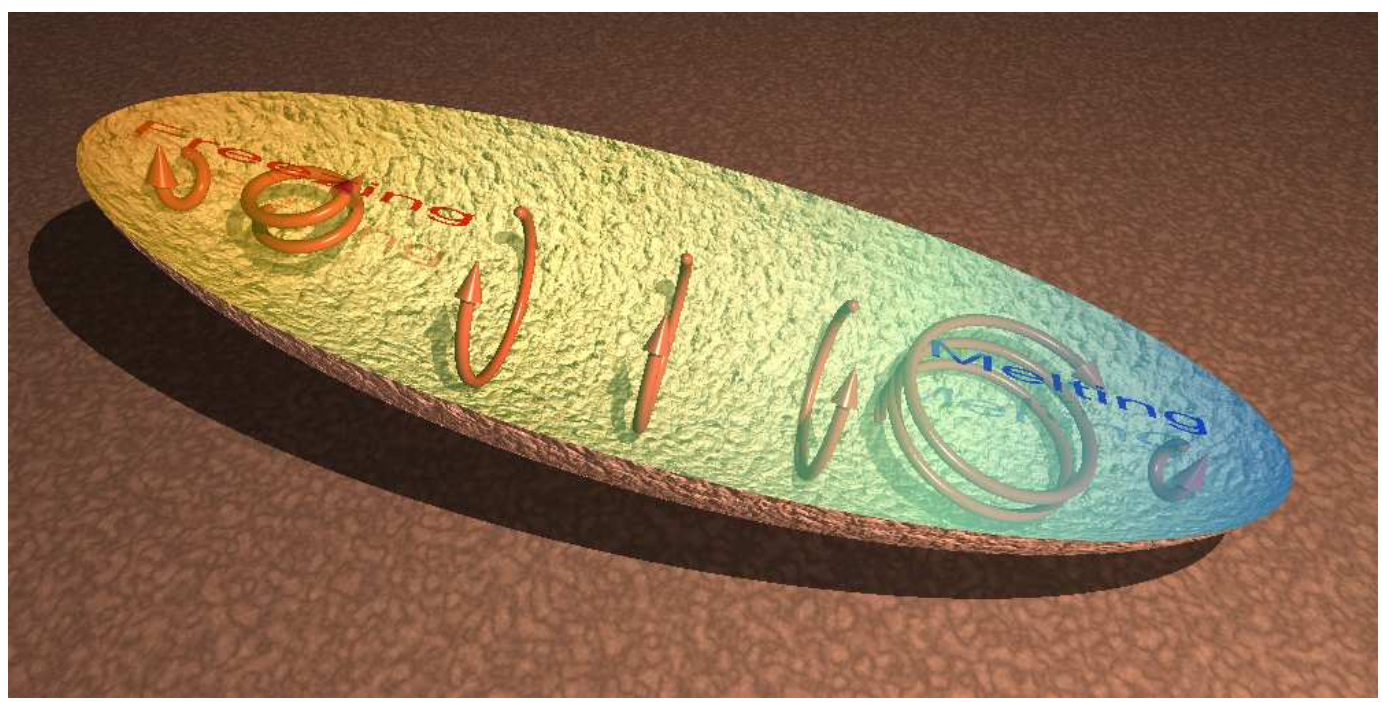

Fig. 5. Sketched circulation and basal mass balance distribution within North-South orientated subglacial lakes like Lake Vostok and Lake Concordia.

Combining our numerical model results with those available for Lake Vostok (Wüest and Carmack, 2000; Williams, 2001; Mayer et al., 2003; Thoma et al., 2007a, 2008b; Filina et al., 2008; Wells and Wettlaufer, 2008) allows an approach to generic conclusions for subglacial lakes (Figure 5): Melting occurs over most parts of a lake, and freezing is restricted to areas with relatively thinner ice. It is likely that the geothermal heat gain in most subglacial lake regions exceeds the heat flux loss through the ice. Even if the heat loss through the ice equals the geothermal heat flux a positive mass balance for the lake would remain, as in freezing areas the temperature gradient within the ice, and hence the heat conduction into the ice, vanishes (Thoma et al., 2008b). This results in a lake growth due to melting and eventually in discharges into a subglacial hydrological network (Gray et al., 2005; Wingham et al., 2006; Fricker et al., 2007). According to our modelling, the flow is baroclinic, and the barotropic component of the flow is split into at least two parts. The dominating constraint is the greatest water column depth of the lake where the main cyclonic/anticyclonic gyres abut. But other bathymetric features, like the ridge separating the northern part of Lake Vostok from the main basin also have impacts on the main flow direction and can generate additional, reversed gyres (Thoma et al., 2007a). This general flow pattern 
superimposes a molecular convection with typical horizontal and vertical velocities of $u_{h} \approx 1.35 \pm 0.13 \mathrm{~mm} / \mathrm{s}$ and $u_{h} \approx 0.81 \pm 0.08 \mathrm{~mm} / \mathrm{s}$, respectively. These velocities strongly depend on the equation of state, which hasn't been validated for sub-Antarctic conditions, yet. However, according to our modelling, the residence time of the water within Lake Concordia is even lower than that of the huge Lake Vostok and hence, it is likely that in all subglacial lakes the dispersion of possible nutrients and biota takes place within decades at most (Thoma et al., 2007b). The modelled averaged horizontal flow is in the same order of magnitude, but according to the representation of the vertical flow the modelled vertical flow is about three orders of magnitude lower. Our model experiment for the medium-size Lake Concordia and its comparison with the results available for the giant Lake Vostok improves our knowledge about subglacial lakes. However, these lakes are still buried below several thousand meters of ice and continue to hold many secrets. Eventually, only drilling into subglacial lakes (e.g., Inman, 2005; Siegert et al., 2007) will reveal most of their mysteries.

Acknowledgement: This work was funded by the DFG through grant MA33471-2. The authors wish to thank Andrea Bleyer for proof reading and three anonymous reviewers for helpful suggestions which improved the manuscript

\section{References}

Blankenship, D., Dec. 2003. Inversion of airborne gravity data over subglacial lakes in East Antarctica. AGU Fall Meeting Abstracts, B446+.

Chen, C.-T. A., Millero, F. J., 1986. Precise thermodynamic properties for natural waters covering only the limnological range. Limnol. Oceanogr. 31 (3), 657-662.

Christner, B. C., Royston-Bishop, G., Foreman, C. F., Arnold, B. R., Tranter, M., Welch, K. A., Lyons, W. B., Tsapin, A. I., Studinger, M., Priscu, J. C., 2006. Limnological conditions in Subglacial Lake Vostok, Antarctica. Limnol. Oceanogr. 51 (6), doi: 10.1038/nature05554.

Filina, I., Blankenship, D., Roy, L., Sen, M., Richter, T., Holt, J., 2004. The bathymetry of two subglacial lakes in East Antarctica derived from airborne gravity and radar sounding data. In: 1st SCAR Open Science Conference: Antarctica and the Southern Ocean in the Global System.

Filina, I., Blankenship, D., Roy, L., Sen, M., Richter, T., Holt, J., 2006. Inversion of airborne gravity data acquired over subglacial lakes in East Antarctica. In: Fütterer, D. (Ed.), Antarctica - Contributions to Global Earth Sciences. Proceedings of the 9th International Symposium on Antarctic Earth Sciences. Springer, pp. 129-134. 
Filina, I. Y., Blankenship, D. D., Thoma, M., Lukin, V. V., Masolov, V. N., Sen, M. K., 2008. New 3D bathymetry and sediment distribution in Lake Vostok: Implication for pre-glacial origin and numerical modeling of the internal processes within the lake. Earth and Planetary Science Letters Earth Pla. Sci. Let., doi:10.1016/j.epsl.2008.09.012.

Fricker, H. A., Scambos, T., Bindschadler, R., Padman, L., 2007. An active subglacial water system in west Antarctica mapped from space. Science 315 (5818), 1544-1548, doi: 10.1126/science.1136897.

Gray, L., Joughin, I., Tulaczyk, S., Spikes, V. B., Bindschadler, R., Jezek, K., 2005. Evidence for subglacial water transport in the West Antarctic Ice Sheet through three-dimensional satellite radar interferometry. Geophys. Res. Lett. 32.

URL http://dx.doi.org/10.1029/2004GL021387

Grosfeld, K., Gerdes, R., Determann, J., 1997. Thermohaline circulation and interaction beneath ice shelf cavities and the adjacent open ocean. J. Geophys. Res. 102 (C7), 15595-15610.

Inman, M., 2005. Antarctic drilling: The plan to unlock Lake Vostok. Science 310 (5748), 611-612, doi: 10.1126/science.310.5748.611.

Jackett, D. R., McDougall, T. J., 1995. Minimal adjustment of hydrographic profiles to achieve static stability. J. Atmos. Ocean. Technol. 12, 381-389.

Kwok, R., Siegert, M. J., Carsey, F. D., 2000. Ice motion over Lake Vostok, Antarctica: constraints on inferences regarding the accreted ice. J. Glaciol. 46, 689-694.

Maule, C. F., Purucker, M. E., Olsen, N., Mosegaard, K., Jul. 2005. Heat Flux Anomalies in Antarctica Revealed by Satellite Magnetic Data. Science 309, 464-467, doi: 10.1126/science.1106888.

Mayer, C., Grosfeld, K., Siegert, M., 2003. Salinity impact on water flow and lake ice in Lake Vostok, Antarctica. Geophys. Res. Lett. 30 (14), 1767, doi:10.1029/2003GL017380.

Millero, F. J., Poisson, A., 1981. International one-atmosphere equation of state of seawater. Deep-Sea Res. 28 (6), 625-629.

Roy, L., Sen, M. K., Blankenship, D. D., Stoffa, P. L., Richter, T. G., 2005. Inversion and uncertainty estimation of gravity data using simulated annealing: An application over Lake Vostok, East Antarctica. Geophysics 70 (1), J1-J12, doi:10.1190/1.1852777.

Siegert, M. J., Behar, A., Bentley, M., Blake, D., Bowden, S., Christoffersen, P., Cockell, C., Corr, H., Cullen, D. C., Edwards, H., Ellery, A., Ellis-Evans, C., Griffiths, G., Hindmarsh, R., Hodgson, D. A., King, E., Lamb, H., Lane, L., Makinson, K., Mowlem, M., Parnell, J., Pearce, D. A., Priscu, J., Rivera, A., Sephton, M. A., Sims, M. R., Smith, A. M., Tranter, M., Wadham, J. L., Wilson, G., Woodward, J., 2007. Exploration of Ellsworth Subglacial Lake: a concept paper on the development, organisation and execution of an experiment to explore, measure and sample the environment of a West Antarctic subglacial lake. Rev. Env. Sci. Bio. 6 (1-3), 161-179, doi: 10.1007/s11157006-9109-9. 
Siegert, M. J., Carter, S., Tabacco, I. E., Popov, S., Blankenship, D. D., 2005. A revised inventory of Antarctic subglacial lakes. Anatarct Sci 17 (3), 453460, doi:10.1017/S0954102005002889.

Souchez, R., Petit, J. R., Jouzel, J., DeAngelis, M., Tison, J., 2003. Reassessing lake Vostok's behavior from existing and new ice core data. Earth Pla. Sci. Let. 217, 163-170.

Studinger, M., Bell, R. E., Tikku, A. A., 2004. Estimating the depth and shape of subglacial Lake Vostok's water cavity from aerogravity data. Geophys. Res. Lett. 31 (L12401), doi:10.1029/2004GL019801.

Thoma, M., Grosfeld, K., Lange, M. A., 2006. Impact of the Eastern Weddell Ice Shelves on water masses in the eastern Weddell Sea. J. Geophys. Res. 111 (C12010), doi:10.1029/2005JC003212.

Thoma, M., Grosfeld, K., Mayer, C., Dec. 2007a. Modelling mixing and circulation in subglacial Lake Vostok, Antarctica. Ocean Dynamics 57 (6), 531-540, doi: 10.1007/s10236-007-0110-9.

Thoma, M., Grosfeld, K., Mayer, C., 2007b. Modelling tracer dispersion in subglacial Lake Vostok, Antarctica. In: Cooper, A. K., Raymond, C. R., et al. (Eds.), Antarctica: A Keystone in a Changing World - Online Proceedings of the 10th ISAES X. Open-File Report 2007-1047, Extended Abstract 052. pp. 1-4.

Thoma, M., Grosfeld, K., Mayer, C., 2008a. Modelling accreted ice in subglacial Lake Vostok, Antarctica. Geophys. Res. Lett. 35 (L11504), 1-6, doi:10.1029/2008GL033607.

Thoma, M., Mayer, C., Grosfeld, K., 2008b. Sensitivity of Lake Vostok's flow regime on environmental parameters. Earth Pla. Sci. Let. 269 (1-2), 242247, doi:10.1016/j.epsl.2008.02.023.

Tikku, A. A., Bell, R. E., Studinger, M., 2002. Lake Concordia: A Second Significant Lake Beneath the East Antarctic Ice Sheet. AGU Fall Meeting Abstracts, B21A-11.

Tikku, A. A., Bell, R. E., Studinger, M., Clarke, G. K. C., 2004. Ice flow field over Lake Vostok, East Antarctica inferred by structure tracking. Earth Pla. Sci. Let. 227, 249-261, doi:10.1016/j.epsl.2004.09.021.

Tikku, A. A., Bell, R. E., Studinger, M., Clarke, G. K. C., Tabacco, I., Ferraccioli, F., 2005. Influx of meltwater to subglacial Lake Concordia, east Antarctica. J. Glaciol. 51 (172), 96-104.

Walsh, D., 2002. A note on eastern-boundary intensification of flow in Lake Vostok. Ocean Modelling 4, 207-218.

Wells, M. G., Wettlaufer, J. S., 2008. Circulation in Lake Vostok: A laboratory analogue study. Geophys. Res. Lett. 35 (L03501), 1-5, doi:10.1029/2007GL032162.

Williams, M. J. M., 2001. Application of a three-dimensional numerical model to Lake Vostok: An Antarctic subglacial lake. Geophys. Res. Lett. 28 (3), $531-534$.

Wingham, D. J., Siegert, M. J., Shepherd, A., Muir, A. S., 2006. Rapid discharge connects Antarctic subglacial lakes. Nature 440 (C6), 1033-1036, 
doi:10.1038nature04660.

Wüest, A., Carmack, E., 2000. A priori estimates of mixing and circulation in the hard-to-reach water body of Lake Vostok. Ocean Modelling 2 (1), $29-43$. 